\title{
Hematopoietic Stem Cells in Regenerative Medicine: Astray or on the Path?
}

\author{
Albrecht M. Müllera Sascha Huppertz ${ }^{a}$ Reinhard Henschler ${ }^{b, c}$ \\ ${ }^{a}$ Institute of Medical Radiology and Cell Research (MSZ) in the Center for Experimental Molecular Medicine (ZEMM), \\ University of Würzburg, Würzburg, Germany; \\ bBlood Center Zürich, Swiss Red Cross, Schlieren, Switzerland; \\ ${ }^{\mathrm{c}}$ Red Cross Blood Service Graubünden, Chur, Switzerland
}

\section{Keywords}

Hematopoietic stem cells - Autologous and allogeneic transplantation - Hematopoietic reconstitution . Hematopoietic cell transplantation in hematopoietic and non-hematopoietic conditions

\section{Summary}

Hematopoietic stem cells (HSCs) are the best characterized adult stem cells and the only stem cell type in routine clinical use. The concept of stem cell transplantation laid the foundations for the development of novel cell therapies within, and even outside, the hematopoietic system. Here, we report on the history of hematopoietic cell transplantation (HCT) and of HSC isolation, we briefly summarize the capabilities of HSCs to reconstitute the entire hemato/lymphoid cell system, and we assess current indications for HCT. We aim to draw the lines between areas where HCT has been firmly established, areas where HCT can in the future be expected to be of clinical benefit using their regenerative functions, and areas where doubts persist. We further review clinical trials for diverse approaches that are based on HCT. Finally, we highlight the advent of genome editing in HSCs and critically view the use of HSCs in non-hematopoietic tissue regeneration.

(C) 2016 S. Karger GmbH, Freiburg

\section{Introduction}

Stem cell transplantation in the context of regenerative medicine relies on the unique potential of stem cells to regenerate the entire stem cell system, including all progenitor and mature cell types, and thereby to reconstitute damaged tissues [1]. This was impressively demonstrated by hematopoietic stem cells (HSCs) which, following transplantation, give rise to all hemato/lymphoid lineages, leading to a life-long reconstitution of the entire hematopoietic system. This exclusive potential makes HSCs a clinically relevant stem cell type. The developmental potential of HSCs is generally regarded as being limited in the sense that HSCs are committed exclusively to their tissue of origin, namely the hematopoietic system. However, some studies claimed that HSCs can also contribute to unrelated tissues and thus show a broad non-tissuerestricted differentiation potential [2]. Here we review basic biological and clinical aspects of HSCs, and we discuss myths, facts, and future directions of clinical HSC biology.

\section{A Brief History of Hematopoietic Cell Transplantation}

Fundamental work on the biology of radiation-induced tissue damage during the first decades following World War II constituted the stem cell research field and generated a series of seminal findings in animal models that paved the way for today's therapeutic use of HSCs. The era of hematopoietic cell transplantation (HCT) began with work done by Lorenz et al. [3] and Jacobson and colleagues [4] who showed that lead shielding of the spleen and bone marrow protected mice from the lethal effects of ionizing radiation and that transplantation of spleen or marrow cells into Xirradiated animals mediated the protection from hematopoietic

\section{KARGER \\ Fax +497614520714

\section{(c) 2016 S. Karger GmbH, Freiburg}

$1660-3796 / 16 / 0434-0247 \$ 39.50 / 0$ 
death. The field of HCT began with these observations: In 1961, Till and McCulloch [2] reported in a landmark paper a method for the quantification of hematopoietic progenitor and stem cells by the spleen colony-forming unit (CFU-s) assay. This paper and subsequent work revealed that the normal hematopoietic compartment is structured as a hierarchy with HSCs at the top and that clonal cells in the marrow can differentiate into all blood cell lineages. In aggregate, the results showed that stem cells are rare cells with two functional attributes that distinguish them from all other cell types in the body: i) They have the capacity to replicate to form daughter cells with a similar developmental potential, that is to self-renew; ii) they have the capacity to differentiate via progenitor cells into a large number of mature cell types that carry out tissuespecific functions [5].

In parallel to the work done to characterize the biological properties of HSCs, there was a sense that before HCT could be used to treat hematological malignancies, the transplantation barrier imposed by differences in surface antigens between donor and recipient cells had to be overcome. In the 1950s and 1960s, a number of small and large animal models were established to elucidate the molecular components of histocompatibility relevant for allogeneic HCT. In 1959, Thomas et al. [6, 7] reported that bone marrow from a healthy identical twin restored the blood system of a leukemic child. This and other observations revealed that a high degree of serological or genetic matching between donor and recipient is required and, of similar importance, that the graft mounted an immune reaction against the leukemia [8]. Building on observations from allogeneic bone marrow transplantations between dogs with matched and unmatched leukocyte antigens and refining the ablative regiment to destroy the tumor cells, Thomas and his team overcame one of the main hurdles of allogeneic cell transplantations by carefully selecting donor/patient matches for human leukocyte antigen (HLA) types before bone marrow transplantation $[9,10]$ and thereby paved the way to the establishment of successful HCTs.

\section{The Entire Hematopoietic System Can Be}

\section{Reconstituted by a Minute Population of Stem Cells}

In spite of the progress made in the development of autologous and allogeneic HCT between 1960 and 1980, it was not clear which cell type is responsible for the complete and long-term repopulation of the hematopoietic system in recipients and whether it can be phenotypically defined. An obstacle to studying HSCs however is that these exquisite cells are found at a very low frequency.

As the mouse is an indispensable model system for studying hematopoiesis, these studies were done on murine bone marrow cells. Early studies aiming to purify HSCs used a separation of cells by size and density [11]. Later, antibodies against mature and progenitor cells plus flow cytometric sorting (FACS) were deployed to prospectively isolate HSCs with the use of a variety of phenotypic surface markers. 30 of the sorted lineage maker negative (LIN-), Thy $1^{\text {low }}$ and Sca1+ cells were sufficient to save half of the lethally irradiated mice and to reconstitute all blood cell types [12]. Further research showed that injection of a single $\mathrm{CD} 34^{\text {low/- }}, \mathrm{c}-\mathrm{Kit}+$, Sca-1+, Kit+, LIN- cell into irradiated mice resulted in long-term reconstitution of the lympho/hematopoietic system [13]. Also alternative surface markers such as the SLAM (signaling lymphocyte activation molecule) receptors (CD150, CD244, and CD48), DNA binding dyes or the aldehyde dehydrogenase activity were used to distinguish and separate mature and progenitor cells from HSCs [14]. The establishment of clonal assays and stringent functional read out systems greatly facilitated the identification of hematopoietic progenitor and stem cells [15].

The search for human HSCs used the murine HSC isolation strategy as a template, including cell separation based on the absence or presence of specific surface markers. Rapidly, the purification of human HSCs centered around the glycoprotein CD34 which is expressed in rare bone marrow cells [16]. CD34 expression ceases during hematopoietic development. The stem cell antigen CD34 enriches clonogenic hematopoietic progenitor cells and CD34+ cells engraft the hematopoietic system in baboons and in patients [17, 18]. After establishing immune-deficient xenograft models for the efficient engraftment of the human hematopoietic system in mice, Bhatia et al. [19] showed that human HSCs have a LIN-, CD34+ and CD38- phenotype. Further multi-parametric flow cytometry and immune phenotyping showed that purified human HSCs express CD34, CD90 and CD49f but not CD38 or CD45RA [20].

The ability to highly purify HSCs facilitates molecular analyses that aim to better understand the growth and differentiation properties of this rare but potent cell type. Purification of HSCs can also be used to develop rational treatment options against leukemic cells. Currently, most clinical HSC transplants use mononuclear cell fractions from bone marrow, peripheral blood, or cord blood. However, techniques which enrich HSCs and deplete accessory cells have been developed and have in part been introduced into clinical practice, as outlined below. For further details on the isolation and molecular regulation of human HSCs see Weissman and Shizuru [21] and Doulatov et al. [20].

\section{Establishment of Hematopoietic Cell Transplantation as a Revolutionary Treatment for Life-Threatening Hematopoietic Diseases}

The success of allogeneic HCT in patients by Thomas and his team $[9,10]$ created worldwide attention and spurred enormous activities to establish this complex treatment for more patients. In addition to acute myeloid leukemia and primary immune deficiencies, HCT was established as a therapy for patients with chronic myeloid leukemia, acute lymphatic leukemia, aplastic anemia, and hemoglobinopathies [22, 23]. Following conditioning by chemoor irradiation therapy and HCT, the regeneration of the hematopoietic system is almost universally achieved within 2-4 weeks. However, major mortality is caused by acute and/or chronic graftversus-host disease, or relapse in the case of malignancy. If stable donor-type hematopoietic chimerism is reached, cure rates are between 30 and $70 \%$ for several malignant diseases and even higher 
Fig. 1. Numbers of HCTs performed in Europe in 2012 by donor type and indication. Shown are numbers of HCTs in patients with the indicated donor types and disease groups as reported by the Registry of the European Society for Blood and Marrow Transplantation (EBMT). Total numbers of HCTs are given in brackets. Data were extracted from [25].

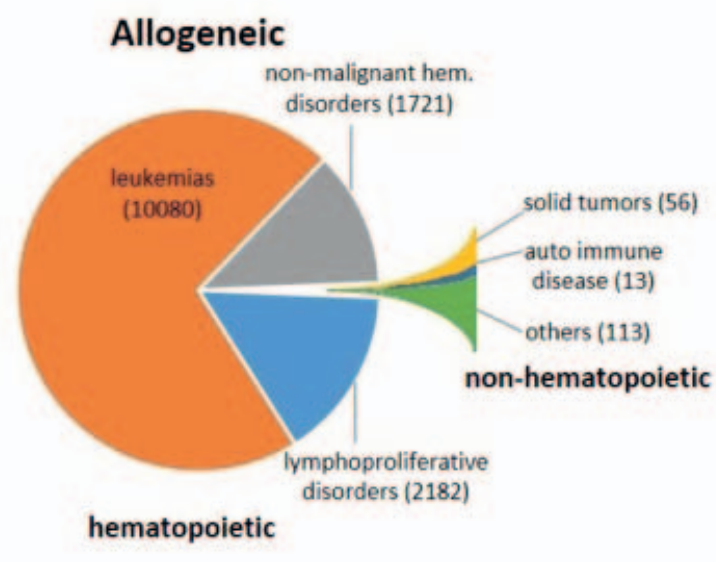

in children [24]. Figure 1 gives an overview on the current diagnoses leading to allogeneic HCTs performed 2012 in Europe. In 2012, 37,818 HCTs were conducted in a total of 33,678 patients $(14,165$ allogeneic, 19,513 autologous) [25]. The diagnoses comprise leukemic and lymphoproliferative disorders as well as benign inherited hematopoietic diseases, and only a relatively minute fraction of other indications.

Allogeneic and autologous HCTs represent fundamentally different transplantation strategies. In allogeneic HCT, in addition to a new hematopoietic system, also a complete foreign immune system is transplanted. This includes the potential generation of an anti-leukemia reactivity. Allogeneic HCT requires matched donors and elaborated pre-transplant diagnostics to select the best possible transplant as well as highly complex treatment schedules. In autologous HCT the patient's own HSCs are transplanted. Autologous HCT is the preferred treatment option for patients with tumors of the lymphatic system such as multiple myeloma or various forms of non-Hodgkin's lymphoma (NHL) [26]. Autologous HCT has evolved as an alternative for patients who are physically less suitable and/or lack a suitable donor. Autologous HCT has also been extended to patients with some solid tumors, including pediatric and germ cell tumors [27]. In a more recent approach, autologous HCT has been established for the treatment of autoimmune diseases following rigorous depletion of autoreactive lymphocytes [28]. Whereas in solid tumors HSCs mediate primarily the reconstitution of the hematopoietic system, in autoimmune diseases they are mainly employed to replenish lymphopoiesis after dose-intensified eradication of lymphocytes. Current diagnoses for autologous HCT are also summarized in figure 1.

\section{Prerequisites for the Clinical Use of Hematopoietic Cell Transplantation}

The routine clinical use of HCT also required the overcoming of a number of other critical hurdles. Firstly, effective preparatory regimens which safeguard the thorough and permanent ablation of malignant cells and which at the same time suppress the host's immune system were developed $[24,29]$. Secondly, the selection of suitable donors by quality-assured HLA typing was established using standardized nomenclature for HLA types and worldwide cooperation of donor registries [30,31]. Thirdly, methodologies were developed intended to pharmacologically suppress immune reactions during the engraftment phase, specifically graft-versushost disease and host-versus-graft reactions resulting in engraftment failure $[23,31]$. Also, substitution of platelets and erythrocytes by transfusions and refined antibiotic regimens to prevent infection during hematopoietic aplasia including antiviral and anti-fungal medications may become necessary [24]. Finally, protocols for a sensitive monitoring of the regeneration of the hematopoietic and immune cells and the early recognition of potential disease relapses were established [32]. For a more detailed review on the current status of both allogeneic and autologous HCT see Gyurkocza et al. [24].

\section{What Is an Ideal Hematopoietic Cell Graft?}

During the establishment period of HCT, bone marrow obtained under general anesthesia was used as a source of hematopoietic cells. The availability of hematopoietic colony stimulating factors (CSFs) and the observation that short-term granulocyte-macrophage colony-stimulating factor (GM-CSF) treatment mobilizes HSCs into the blood, led to the establishment of peripheral blood stem and progenitor cells (PBSC) as an efficient and easily obtainable HCT graft $[33,34]$. In a series of single patient trials in children for whom no donor was available, cord blood preserved from their younger siblings has been introduced as a third source of HSCs in the clinic. This transplant source has been originally established for patients in lack of a suitable donor using either family members or unrelated donors, and has since been established as a valuable transplant source for children $[35,36]$. Routinely, most current HCT grafts nowadays contain in addition to HSCs both accompanying progenitor cells and different mature cell types (fig. 2). Co-transplanted lymphocytes constitute effectors of acute and chronic graft-versus-host disease and are potentially highly detrimental to the treatment outcome. This pushed the development of technologies that remove lymphocytes from the graft or, 
Fig. 2. Graft types used for HCTs. Upon harvest, grafts for HCT can be: unfractionated bone marrow, mobilized peripheral blood (PBSC) or cord blood that contain progenitors with multi- or dual lineage differentiation potential together with mature cells of different lineages. Alternative grafts are lineage-depleted cell populations, cell populations that were selectively expanded in vitro, or HSCs transduced with a viral vector encoding an intact copy of a mutated gene. T-LYs cannot reconstitute hematopoiesis, but selected and/or genetically engineered T-LYs (e.g. CAR T cells) could erase leukemic cells. Here, HSCs include hematopoietic stem and progenitor cells. Cell lineages are symbolized using indicated colors as shown in the legend. $\mathrm{GR}=$ Granulocyte; MEG-E = megakaryocyteerythrocyte; $\mathrm{MO}=$ monocyte, $\mathrm{NK}=$ natural killer; Ly = lymphocyte.

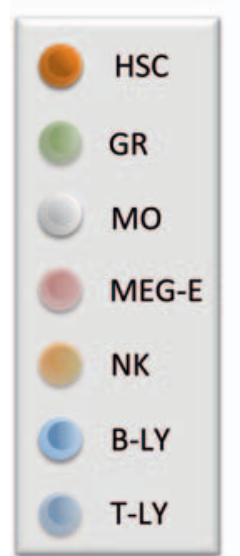

alternatively, allow enrichment of HSCs by positive selection [3739]. The possibility to deplete $T$ and $B$ lymphocytes down to low numbers in HSC grafts or, alternatively, by in vivo depletion using post-transplant cyclophosphamide has widened the use of allogeneic HCT in children by using parents as donors in haploidentical stem cell transplantation [40]. Natural killer (NK) cells contained in the graft were found beneficial, since they can carry anti-leukemic potential and may be preserved or also enriched [41]. The $\mathrm{CD} 34+$ cell fraction has been found to contain virtually all cells required for long-term and multi-lineage hematopoietic engraftment, but no immune effector cells. This is of importance for HCT in patients with inherited immune deficiencies for whom no isogenic donors were available [42].

The possibility to 'add back' donor lymphocytes that were either separately frozen at the time of HSC harvest or collected from the donor later in critical clinical situations weeks to months after HCT has widened the therapeutic options of HCT and supports the concept of the still somewhat enigmatic 'graft-versus-leukemia' effector cells [43]. Thus, manipulated HCT grafts have been implemented into clinical practice mainly in allogeneic HCT to allow for a better control of immune rejection and graft-versus-host disease. More recently, approaches to deplete transplanted immune cells by application of cyclophosphamide immediately post transplantation yielded promising results. This could, at least in part, make some graft manipulations superfluous [44, 45].

\section{What Are Current Challenges in Hematopoietic Cell Transplantation?}

\section{Ethnical Issues}

In most parts of the Western hemisphere, it is currently possible to find a donor with a suitable HLA match for the vast majority of patients. For members of many non-Caucasian population groups
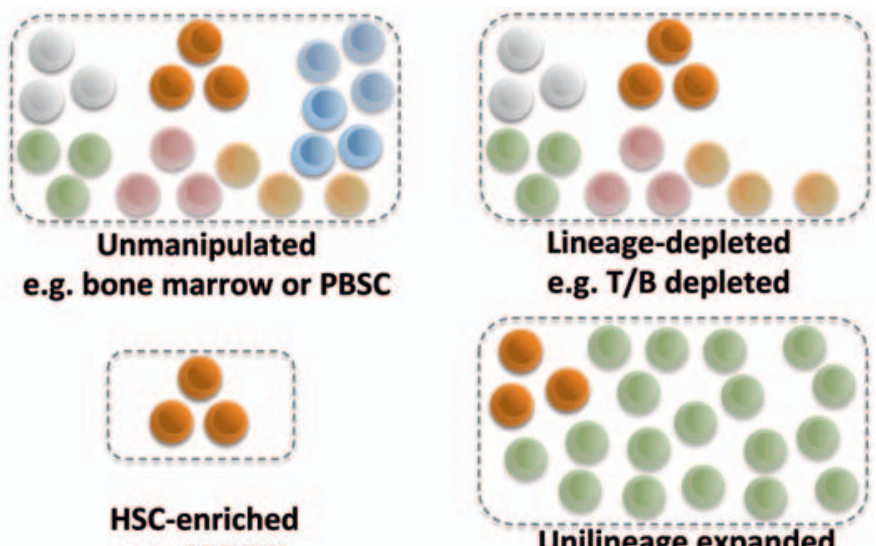

e.g. CD34pos

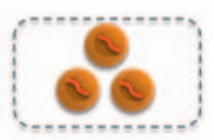

Gene-corrected HSCs

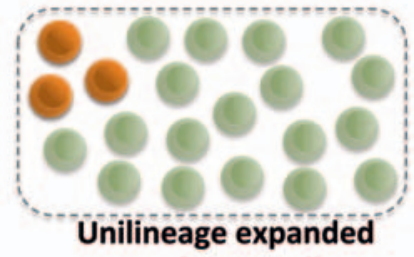

e.g. for GR cells

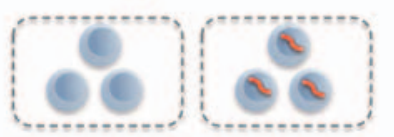

Antigen-selected T-LY Genetically engineered T-LY

however, the chance to find a suitable donor is still much lower. Moreover, HCT has been established only slowly in less developed countries. This imposes great challenges on the stakeholders to transfer at least some of the benefits of HCT to more patients worldwide, supported by international programs such as the World Marrow Donor Association (WMDA) that aim to improve access to HCTs [46].

Understanding Better the Immunology Involved in Graft-versus-

Host Disease and in Antitumor Activity

In a proportion of patients, immunological rejection or graftversus-host disease after allogeneic HCT represents a major clinical problem. Studies are under way to evaluate how effective the current HLA matching and donor selections are performed and in which way improvements could be implemented, e.g. through the use of additional HLA or non-HLA determinants [46, 47]. Moreover, haploidentical HCT harbors potential to make HCT accessible to more patient groups in the future $[40,42]$. In a different approach, the toxicity of the conditioning regimes was reduced [48, 49]. The field of HCT application could potentially be widened, since allogeneic HCT induces immune tolerance to transplanted tissues and organs, e.g. the kidney [50]. This holds great promise to improve survival and function of transplanted organs, and possibly other issue transplants, but is still at a pre-clinical stage and does not necessarily need HSCs. In the area of leukemia therapy, a challenging question is the identification and characterization of the cell population(s) that cause the graft-versus-leukemia effect [51]. The identification of these cells serves as a means to analyze their presence and numbers in the donor and to isolate and infuse them in distinct clinical situations. The genetic modification to immune effector cells, e.g. T lymphocytes with recombinant chimeric antigen receptors as a tool to re-direct these cells to tumors, has been developed as a clinical tool in the last decade, leading to therapeutic successes already in children with acute lymphatic leukemia [52, 53]. 


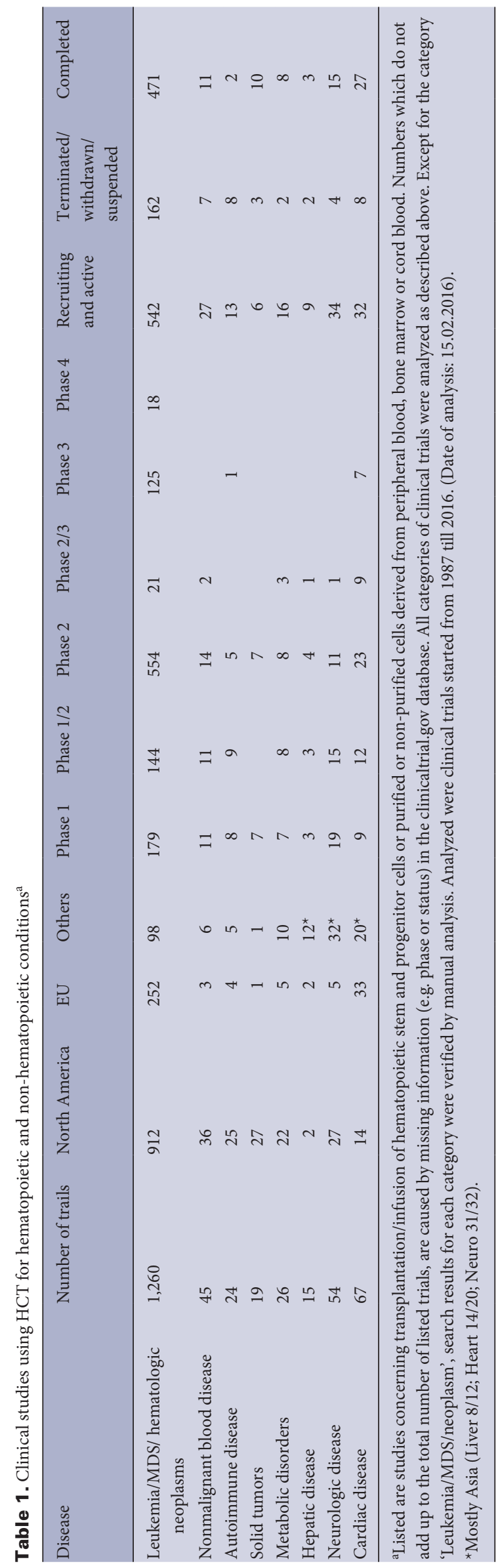

\section{Insufficient HSC Numbers}

The banking of cord blood HSCs has led to a further increase in the availability of HCT grafts with suitable HLA types for patients in need of allogeneic HCT [35]. However, small HSC numbers in these grafts correlate with delayed or even absent hematopoietic reconstitution. Both, double and triple cord blood transplantation protocols as well as ex vivo expansion protocols on stromal cell layers have demonstrated a potential to overcome engraftment deficits and to reduce graft failure rates [54]. Co-transplantation of mesenchymal stromal cells (MSCs), of 'facilitating' lymphocytes, or of ex vivo expanded neutrophil precursor cells may improve engraftment of transplants containing low HSC numbers, yet require further clinical development (fig. 2) [54-57]. Also, experimental work is needed to understand the molecular mechanisms that regulate the self-renewal and differentiation of HSCs. Recent pre-clinical studies indicated that strategies which specifically target both global and gene-specific histone modifications are effective for the robust ex vivo expansion of hematopoietic progenitor and stem cells [58-60]. The refinement and optimization of HSC expansion strategies using chromatin-modifying agents provides a potential new avenue for manufacturing increased numbers of HSCs.

\section{New Stem Cell Sources}

Potential sources for future HCT constitute embryonic stem cells, induced pluripotent stem cells and, lately, directly reprogrammed cells [61]. These strategies however are currently at a very early experimental stage, and their clinical use critically depends on the development of robust differentiation protocols that generate sufficient HCT for long-term and multi-lineage reconstitution in due time. Also, safety issues have to be clarified. It may prove difficult to carry these new strategies to transplantable progenitor and stem cells; however, they may generate mature cells such as erythrocytes for transplantation [62]. Rather than for transplantation therapy, these cell sources will become relevant for in vitro disease modeling, drug discovery, and toxicology studies.

\section{Hematopoietic Cell Transplantations in Clinical Trials for Tissue Regeneration: Current Status}

Clinical trials using HCT can be divided in two groups: one group are studies in which HCT aims at reconstituting the hematopoietic system (e.g. blood or bone marrow malignancies, nonmalignant blood disease, solid tumors or autoimmune disease). In studies of the second group, the HCT is supposed to affect other tissues, such as liver, heart or neurologic tissues. As shown in table 1, approximately $92 \%$ of the clinical HCT trials aiming at reconstitution of the hematopoietic system are performed in the EU and North America. Notably, the relatively new emerging approaches aiming at regenerating non-hematopoietic tissues by HSC transplantation are mostly carried out in other countries than North America or the EU. Out of 136 studies concerning liver disease, heart disease, or neurologic disease, $47.1 \%$ are performed outside the EU and North America, most of them (38.9\%) in Asia. 
This might be caused by a recent boom of the clinical trial sector in Asian countries and cultural issues as well. At this time, it seems difficult to draw conclusions regarding both the efficacy of these trials and the mechanisms by which they benefit non-hematopoietic tissues.

\section{Myths, Facts, and Future Directions Using Hematopoietic Cell Transplantation to Regenerate Hematopoietic and Non-Hematopoietic Tissues}

As indicated in the previous chapters, HSCs are the best characterized somatic stem cell type, and to date HSCs are the only stem cells in routine clinical use. Despite the extended knowledge on HSC biology, some time ago it came as a great surprise that several reports claimed that differentiating HSCs may cross germ layer boundaries and that they might be capable to differentiate into mature cells of unrelated stem cell systems. For example, pre-clinical studies suggested that HSCs from bone marrow and cord blood should have the ability to repair the infarcted heart, improving function and survival in a murine systems. Immediately, this observation triggered the launch not only of pre-clinical but, surprisingly, also of numerous clinical studies [63, 64]. Based on these claims, a general debate emerged whether somatic stem cells including HSCs could have a wider, possibly even unlimited differentiation potential similar to pluripotent embryonic stem cells [65]. The hypothesis that adult stem cells can 'transdifferentiate' was based on the concept that the lineage commitment of differentiated cells may be not as fixed as previously believed, and that environmental cues can alter cell lineage identities [66]. However, further studies using state-of-the-art cell and stringent molecular tools that allowed the clonal tracking of cells failed to demonstrate reproducibility and seriously challenged the notion of adult stem cell plasticity. In contrast to the hypothesized 'transdifferentiation', these studies revealed that the majority of the transplanted HSCs either died or differentiated into hematopoietic cells and that some progeny of HSCs can, at low frequencies, fuse with unrelated cells such as cardiomyocytes $[67,68]$. Furthermore, a critical evaluation of clinical trials in patients with acute and chronic heart disease from diverse etiologies revealed that bone marrow cells neither engrafted over significant time periods nor differentiated into cardiomyocytes, and only modest short- und no long-term benefits of transplanted bone marrow cells were seen [69]. Similarly, proof is lacking in both pre-clinical and also clinical studies that HSCs confer regenerative functions for tissue systems other than lymphohematopoiesis. Thus, the developmental potential of HSCs, similar as that of other adult stem cell types, is restricted to their innate stem cell system and tissue. The benefit of ectopically transplanted HSCs therefore most likely is based on paracrine effects [70]. Considered with hindsight, this episode calls for great caution before pushing laboratory studies into the clinics and prematurely publishing paradigm shifts.

A dream that has come true for basic and applied researchers is the development of tools for the efficient and safe modification of specific genomic loci in HSCs and in other cell types. To date, gene delivery has generally relied on the use of viral vectors with random genome integration into the host DNA and their inherent difficult to influence and variable gene expression levels. In the past few years, specific gene 'scissors' including zinc-finger nucleases (ZFN), transcription-activator-like effector nucleases (TALENs) and CRISPR/Cas9 (clustered regularly interspaced short palindromic repeats/RNA-guided nuclease CAS9) were developed for the efficient modification of any genetic loci in any cell type [71]. The RNA-guided CRISPR/Cas9 genome editing tool has particularly revolutionized basic and applied science similar to the polymerase chain reaction (PCR) technology, which opened new avenues of genetic testing and manipulation. In nature, CRISPR/Cas9 is part of a bacterial defense system. The CRISPR/Cas9-mediated genome editing is a new development, and its applicability in a variety of cell types including early embryonic and adult stem cells such as murine and human HSCs was shown [72, 73]. Furthermore, the genomes of monkey and human zygotes were efficiently modified by CRISPR/Cas9, although the genomes also contained unwanted off-target mutations $[74,75]$. The feasibility of human germ line gene modification sparked high-profile debates about the ethical implications of such work.

Clinical genome editing was first described in 2009 using ZFNbased gene editing of the HIV receptor CCR5 in autologous CD4+ $\mathrm{T}$ cells of HIV patients [76], and a ZFN-based gene editing trial to prove the feasibility of a genetic therapy in hemophilia patients is underway [77]. The potential of this technology for a genetic therapy of multiple disease-causing mutations such as $\beta$-thalassemia or primary immune deficiencies is currently being explored [78, 79]. The newly engineered high-fidelity Cas 9 variant with no detectable off-target effects provides a further advance for the potential therapeutic application of CRISPR/Cas9 genome editing tools [80]. In conclusion, the possibility and first clinical application of precise genetic modification of HSCs is evidence that the age of clinical genome engineering has begun.

\section{Outlook}

As reviewed above, HCT developed from an experimental concept to a safe clinical cure for an ever-increasing number of indications related to hematopoietic regeneration. In contrast, the role of HSCs in the regeneration of unrelated tissues lacks proof. Despite the firm anchorage of HCT in everyday clinical practice, the HSC field still faces critical challenges, such as insufficiencies in donor repertoire for a number of ethnicities which is increasingly overcome by haplo-HCT, insufficient HSC numbers e.g. in cord blood samples, a lack of efficient HSC expansion protocols, innovative ways to fine-tune immune suppression as well as reagents and methods that allow to better detect, isolate and culture-expand tumor-targeting immune cells. Both basic and clinical research communities will have to intensify their joint efforts to further develop evidence-based cures in order to give more, and also more elderly, patients access to the benefits of HCT. 


\section{Acknowledgements}

The authors thank Martin Stoddart for his critical reading of the manuscript and Martin Hildebrandt for suggestions and discussion. This work was supported by a grant from the German Research Council (DFG, SPP1463) to AMM.

\section{Disclosure Statement}

The authors declare no competing interests.

\section{References}

1 Trounson A, McDonald C: Stem cell therapies in clinical trials: progress and challenges. Cell Stem Cell 2015; 17:11-22.

2 Till JE, McCulloch EA: A direct measurement of the radiation sensitivity of normal mouse bone marrow cells. Radiat Res 1961;14:213-222.

3 Lorenz E, Uphoff D, Reid TR, Shelton E: Modification of irradiation injury in mice and guinea pigs by bone marrow injections. J Natl Cancer Inst 1951;12:197-201.

4 Jacobson LO, Marksk EK, Robsonk MJ, Gastonk EO, Zirklek RE: Effect of spleen protection on mortality following X-irradiation. J Lab Clin Med 1949;34:1538 1543

5 Chao MP, Seita J, Weissman IL: Establishment of a normal hematopoietic and leukemia stem cell hierarchy. Cold Spring Harb Symp Quant Biol 2008;73:439-449.

6 Thomas ED, Lochte HL Jr, Lu WC, Ferrebee JW: Intravenous infusion of bone marrow in patients receiving radiation and chemotherapy. N Engl J Med 1957;257: 491-496.

7 Thomas ED, Lochte HL Jr, Cannon JH, Sahler OD, Ferrebee JW: Supralethal whole body irradiation and isologous marrow transplantation in man. J Clin Invest 1959;38:1709-1716.

8 Barnes DW, Corp MJ, Loutit JF, Neal FE: Treatment of murine leukaemia with $\mathrm{X}$ rays and homologous bone marrow; preliminary communication. Br Med J 1956; 2:626-627.

9 Thomas ED, LeBlond R, Graham T, Storb R: Marrow infusions in dogs given midlethal or lethal irradiation. Radiat Res 1970;41:113-124

10 Thomas ED, Buckner CD, Rudolph RH, Fefer A, Storb R, Neiman PE, Bryant JI, Chard RL, Clift RA, Epstein RB, Fialkow PJ, Funk DD, Giblett ER, Lerner KG, Reynolds FA, Slichter S: Allogeneic marrow grafting for hematologic malignancy using HL-A matched donor-recipient sibling pairs. Blood 1971;38:267-287.

-11 Iscove NN, Messner H, Till JE, McCulloch EA: Human marrow cells forming colonies in culture: analysis by velocity sedimentation and suspension culture. Ser Haematol 1972;5:37-49.

12 Spangrude GJ, Heimfeld S, Weissman IL: Purification and characterization of mouse hematopoietic stem cells. Science 1988;241:58-62.

13 Osawa M, Hanada K, Hamada H, Nakauchi H: Longterm lymphohematopoietic reconstitution by a single CD34-low/negative hematopoietic stem cell. Science 1996;273:242-245.

14 Kiel MJ, Yilmaz OH, Iwashita T, Yilmaz OH, Terhorst C, Morrison SJ: Slam family receptors distinguish hematopoietic stem and progenitor cells and reveal endothelial niches for stem cells. Cell 2005;121:1109-1121.

15 Dykstra B, Olthof S, Schreuder J, Ritsema M, de Haan $\mathrm{G}$ : Clonal analysis reveals multiple functional defects of aged murine hematopoietic stem cells. J Exp Med 2011;208:2691-2703.

16 Civin CI, Strauss LC, Brovall C, Fackler MJ, Schwartz JF, Shaper JH: Antigenic analysis of hematopoiesis. III. A hematopoietic progenitor cell surface antigen defined by a monoclonal antibody raised against $\mathrm{kg}$ - $1 \mathrm{a}$ cells. J Immunol 1984;133:157-165.
17 Berenson RJ, Andrews RG, Bensinger WI, Kalamasz D, Knitter G, Buckner CD, Bernstein ID: Antigen CD34+ marrow cells engraft lethally irradiated baboons. J Clin Invest 1988;81:951-955.

18 Berenson RJ, Bensinger WI, Hill R, Andrews RG, Garcia-Lopez J, Kalamasz DF, Still BJ, Buckner CD, Bernstein ID, Thomas ED: Stem cell selection - clinical experience. Prog Clin Biol Res 1990;333:403-410; discussion 411-413.

19 Bhatia M, Wang JC, Kapp U, Bonnet D, Dick JE: Purification of primitive human hematopoietic cells capable of repopulating immune-deficient mice. Proc Natl Acad Sci U S A 1997;94:5320-5325.

20 Doulatov S, Notta F, Laurenti E, Dick JE: Hematopoiesis: a human perspective. Cell Stem Cell 2012;10:120-136.

21 Weissman IL, Shizuru JA: The origins of the identification and isolation of hematopoietic stem cells, and their capability to induce donor-specific transplantation tolerance and treat autoimmune diseases. Blood 2008;112:3543-3553.

22 Little MT, Storb R: History of haematopoietic stem-cel transplantation. Nat Rev Cancer 2002;2:231-238

23 Gratwohl A, Niederwieser D: History of hematopoietic stem cell transplantation: evolution and perspectives. Curr Probl Dermatol 2012;43:81-90.

24 Gyurkocza B, Rezvani A, Storb RF: Allogeneic hematopoietic cell transplantation: the state of the art. Expert Rev Hematol 2010;3:285-299.

25 Passweg JR, Baldomero H, Peters C, Gaspar HB, Cesaro S, Dreger P, Duarte RF, Falkenburg JH, Farge-Bancel D, Gennery A, Halter J, Kroger N, Lanza F, Marsh J, Mohty M, Sureda A, Velardi A, Madrigal A; European Society for Bone Marrow Transplantation (EBMT): Hematopoietic SCT in Europe: data and trends in 2012 with special consideration of pediatric transplantation. Bone Marrow Transplant 2014;49:744-750.

26 Majhail NS, Farnia SH, Carpenter PA, Champlin RE, Crawford S, Marks DI, Omel JL, Orchard PJ, Palmer J, Saber W, Savani BN, Veys PA, Bredeson CN, Giralt $\mathrm{SA}$, LeMaistre CF: Indications for autologous and allogeneic hematopoietic cell transplantation: Guidelines from the American Society for Blood and Marrow Transplantation. Biol Blood Marrow Transplant 2015; 21:1863-1869.

27 Einhorn LH, Williams SD, Chamness A, Brames MJ, Perkins SM, Abonour R: High-dose chemotherapy and stem-cell rescue for metastatic germ-cell tumors. N Engl J Med 2007;357:340-348.

28 Sullivan KM, Muraro P, Tyndall A: Hematopoietic cell transplantation for autoimmune disease: updates from Europe and the United States. Biol Blood Marrow Transplant 2010;16:S48-56

29 Mathe G, Thomas ED, Ferrebee JW: The restoration of marrow function after lethal irradiation in man: a review. Transplant Bull 1959;6:407-409.

30 Navarro WH, Switzer GE, Pulsipher M: National marrow donor program session: donor issues. Biol Blood Marrow Transplant 2013;19(1 suppl):S15-19.

31 Thomas ED: A history of haemopoietic cell transplantation. Br J Haematol 1999; 105:330-339.
32 Nierkens S, Lankester AC, Egeler RM, Bader P, Locatelli F, Pulsipher MA, Bollard CM, Boelens JJ; Westhafen Intercontinental Group: Challenges in the harmonization of immune monitoring studies and trial design for cell-based therapies in the context of hematopoietic cell transplantation for pediatric cancer patients. Cytotherapy 2015;17:1667-1674.

33 Siena S, Bregni M, Gianni AM: Mobilization of peripheral blood progenitor cells for autografting: Chemotherapy and G-CSF or GM-CSF. Baillieres Best Pract Res Clin Haematol 1999;12:27-39.

34 Anasetti C, Logan BR, Lee SJ, Waller EK, Weisdorf DJ, Wingard JR, Cutler CS, Westervelt P, Woolfrey A, Couban S, Ehninger G, Johnston L, Maziarz RT, Pulsipher MA, Porter DL, Mineishi S, McCarty JM, Khan SP, Anderlini P, Bensinger WI, Leitman SF, Rowley SD, Bredeson C, Carter SL, Horowitz MM, Confer DL; Blood and Marrow Transplant Clinical Trials Network: Peripheral-blood stem cells versus bone marrow from unrelated donors. N Engl J Med 2012;367:1487-1496.

35 Gluckman E, Ruggeri A, Rocha V, Baudoux E, Boo M, Kurtzberg J, Welte K, Navarrete C, van Walraven SM Eurocord, Netcord, World Marrow Donor Association and National Marrow Donor Program: Family-directed umbilical cord blood banking. Haematologica 2011;96:1700-1707.

36 Danby R, Rocha V: Improving engraftment and immune reconstitution in umbilical cord blood transplantation. Front Immunol 2014;5:68.

37 Shpall EJ, Jones RB, Bearman SI, Stemmer SM, Purdy $\mathrm{MH}$, Heimfeld S, Berenson RJ: Positive selection of CD34+ hematopoietic progenitor cells for transplantation. Stem Cells 1993;11(suppl 3):48-49.

38 Miltenyi S: Cd34+ selection: the basic component for graft engineering. Oncologist 1997;2:410-413.

- 39 Locatelli F, Bauquet A, Palumbo G, Moretta F, Bertaina A: Negative depletion of alpha/beta+ T cells and of CD19+ B lymphocytes: a novel frontier to optimize the effect of innate immunity in HLA-mismatched hematopoietic stem cell transplantation. Immunol Lett 2013;155:21-23.

40 Oevermann L, Lang P, Feuchtinger T, Schumm M, Teltschik HM, Schlegel P, Handgretinger R: Immune reconstitution and strategies for rebuilding the immune system after haploidentical stem cell transplantation. Ann N Y Acad Sci 2012;1266:161-170.

41 Ruggeri L, Parisi S, Urbani E, Curti A: Alloreactive natural killer cells for the treatment of acute myeloid leukemia: from stem cell transplantation to adoptive immunotherapy. Front Immunol 2015;6:479.

42 Reisner Y, Aversa F, Martelli MF: Haploidentical hematopoietic stem cell transplantation: state of art. Bone Marrow Transplant 2015;50(suppl 2):S1-5.

43 Kolb HJ: Graft-versus-leukemia effects of transplantation and donor lymphocytes. Blood 2008;112:43714383

44 Al-Homsi AS, Roy TS, Cole K, Feng Y, Duffner U: Post-transplant high-dose cyclophosphamide for the prevention of graft-versus-host disease. Biol Blood Marrow Transplant 2015;21:604-611. 
45 Bashey A: Peripheral blood stem cells for T cell-replete nonmyeloablative hematopoietic transplants using post-transplant cyclophosphamide. Biol Blood Marrow Transplant 2014;20:598-599.

- 46 Bochtler W, Maiers M, Bakker JN, Oudshoorn M, Marsh SG, Baier D, Hurley CK, Muller CR: World marrow donor association framework for the implementation of HLA matching programs in hematopoietic stem cell donor registries and cord blood banks. Bone Marrow Transplant 2011;46:338-343.

47 Bacigalupo A: Matched and mismatched unrelated donor transplantation: is the outcome the same as for matched sibling donor transplantation? Hematol Am Soc Hematol Educ Program 2012;2012:223-229.

-48 Slavin S, Nagler A, Naparstek E, Kapelushnik Y, Aker M, Cividalli G, Varadi G, Kirschbaum M, Ackerstein A, Samuel S, Amar A, Brautbar C, Ben-Tal O, Eldor A, Or R: Nonmyeloablative stem cell transplantation and cell therapy as an alternative to conventional bone marrow transplantation with lethal cytoreduction for the treatment of malignant and nonmalignant hematologic diseases. Blood 1998;91:756-763.

49 Reshef R, Porter DL: Reduced-intensity conditioned allogeneic SCT in adults with AML. Bone Marrow Transplant 2015;50:759-769.

50 Zakrzewski JL, van den Brink MR, Hubbell JA: Overcoming immunological barriers in regenerative medicine. Nat Biotechnol 2014;32:786-794.

51 Ramos CA, Heslop HE, Brenner MK: CAR-T cell therapy for lymphoma. Annu Rev Med 2016;67:165-183

52 Stauss HJ, Morris EC, Abken H: Cancer gene therapy with $\mathrm{T}$ cell receptors and chimeric antigen receptors. Curr Opin Pharmacol 2015;24:113-118.

53 Weiden PL, Flournoy N, Thomas ED, Prentice R, Fefer A, Buckner CD, Storb R: Antileukemic effect of graftversus-host disease in human recipients of allogeneicmarrow grafts. N Engl J Med 1979;300:1068-1073.

54 Mehta RS, Rezvani K, Olson A, Oran B, Hosing C, Shah N, Parmar S, Armitage S, Shpall EJ: Novel techniques for ex vivo expansion of cord blood: clinical trials. Front Med (Lausanne) 2015;2:89.

55 Bernardo ME, Fibbe WE: Mesenchymal stromal cells and hematopoietic stem cell transplantation. Immunol Lett 2015;168:215-221.

56 Kallekleiv M, Larun L, Bruserud O, Hatfield KJ: Cotransplantation of multipotent mesenchymal stromal cells in allogeneic hematopoietic stem cell transplantation: a systematic review and meta-analysis. Cytotherapy 2016;18:172-185.

57 McNiece I, Jones R, Bearman SI, Cagnoni P, Nieto Y, Franklin W, Ryder J, Steele A, Stoltz J, Russell P, McDermitt J, Hogan C, Murphy J, Shpall EJ: Ex vivo expanded peripheral blood progenitor cells provide rapid neutrophil recovery after high-dose chemotherapy in patients with breast cancer. Blood 2000;96:3001-3007.
58 Obier N, Uhlemann CF, Muller AM: Inhibition of histone deacetylases by trichostatin a leads to a HOXB4independent increase of hematopoietic progenitor/ stem cell frequencies as a result of selective survival. Cytotherapy 2010;12:899-908.

59 Varagnolo L, Lin Q, Obier N, Plass C, Dietl J, Zenke M, Claus R, Muller AM: Prc2 inhibition counteracts the culture-associated loss of engraftment potential of human cord blood-derived hematopoietic stem and progenitor cells. Sci Rep 2015;5:12319.

60 Milhem M, Mahmud N, Lavelle D, Araki H, DeSimone J, Saunthararajah Y, Hoffman R: Modification of hematopoietic stem cell fate by 5aza 2'deoxycytidine and trichostatin A. Blood 2004;103:4102-4110.

61 Vo LT, Daley GQ: De novo generation of HSCS from somatic and pluripotent stem cell sources. Blood 2015; 125:2641-2648

62 Ebihara Y, Ma F, Tsuji K: Generation of red blood cells from human embryonic/induced pluripotent stem cells for blood transfusion. Int J Hematol 2012;95: 610-616.

63 Orlic D, Kajstura J, Chimenti S, Jakoniuk I, Anderson SM, Li B, Pickel J, McKay R, Nadal-Ginard B, Bodine DM, Leri A, Anversa P: Bone marrow cells regenerate infarcted myocardium. Nature 2001;410:701-705.

64 Porada CD, Atala AJ, Almeida-Porada G: The hematopoietic system in the context of regenerative medicine. Methods 2016;99:44-61.

65 Wagers AJ, Weissman IL: Plasticity of adult stem cells. Cell 2004;116:639-648.

66 Blau HM, Brazelton TR, Weimann JM: The evolving concept of a stem cell: entity or function? Cell 2001; 105:829-841.

67 Balsam LB, Wagers AJ, Christensen JL, Kofidis T, Weissman IL, Robbins RC: Haematopoietic stem cells adopt mature haematopoietic fates in ischaemic myocardium. Nature 2004;428:668-673.

68 Nygren JM, Jovinge S, Breitbach M, Sawen P, Roll W, Hescheler J, Taneera J, Fleischmann BK, Jacobsen SE: Bone marrow-derived hematopoietic cells generate cardiomyocytes at a low frequency through cell fusion, but not transdifferentiation. Nat Med 2004;10:494-501.

69 Behbahan IS, Keating A, Gale RP: Bone marrow therapies for chronic heart disease. Stem Cells 2015;33: 3212-3227.

70 Frantz S, Vallabhapurapu D, Tillmanns J, Brousos N, Wagner H, Henig K, Ertl G, Muller AM, Bauersachs J: Impact of different bone marrow cell preparations on left ventricular remodelling after experimental myocardial infarction. Eur J Heart Fail 2008;10:119-124.

71 Jinek M, Chylinski K, Fonfara I, Hauer M, Doudna JA, Charpentier E: A programmable dual-RNA-guided DNA endonuclease in adaptive bacterial immunity. Science 2012;337:816-821.
72 Genovese P, Schiroli G, Escobar G, Di Tomaso T, Firrito C, Calabria A, Moi D, Mazzieri R, Bonini C, Holmes MC, Gregory PD, van der Burg M, Gentner B, Montini E, Lombardo A, Naldini L: Targeted genome editing in human repopulating haematopoietic stem cells. Nature 2014;510:235-240.

73 Mandal PK, Ferreira LM, Collins R, Meissner TB, Boutwell CL, Friesen M, Vrbanac V, Garrison BS, Stortchevoi A, Bryder D, Musunuru K, Brand H, Tager AM, Allen TM, Talkowski ME, Rossi DJ, Cowan CA: Efficient ablation of genes in human hematopoietic stem and effector cells using CRISPR/Cas9. Cell Stem Cell 2014;15:643-652.

74 Niu Y, Shen B, Cui Y, Chen Y, Wang J, Wang L, Kang Y, Zhao X, Si W, Li W, Xiang AP, Zhou J, Guo X, Bi Y, Si C, Hu B, Dong G, Wang H, Zhou Z, Li T, Tan T, Pu X, Wang F, Ji S, Zhou Q, Huang X, Ji W, Sha J: Generation of gene-modified cynomolgus monkey via Cas9/ RNA-mediated gene targeting in one-cell embryos. Cell 2014;156:836-843.

75 Liang P, Xu Y, Zhang X, Ding C, Huang R, Zhang Z, Lv J, Xie X, Chen Y, Li Y, Sun Y, Bai Y, Songyang Z, Ma W, Zhou C, Huang J: CRISPR/Cas9-mediated gene editing in human tripronuclear zygotes. Protein Cell 2015;6:363-372.

76 Tebas P, Stein D, Tang WW, Frank I, Wang SQ, Lee G, Spratt SK, Surosky RT, Giedlin MA, Nichol G, Holmes MC, Gregory PD, Ando DG, Kalos M, Collman RG, Binder-Scholl G, Plesa G, Hwang WT, Levine BL, June $\mathrm{CH}$ : Gene editing of CCR5 in autologous CD4 T cells of persons infected with HIV. N Engl J Med 2014;370: 901-910.

77 Sharma R, Anguela XM, Doyon Y, Wechsler T, DeKelver RC, Sproul S, Paschon DE, Miller JC, Davidson RJ, Shivak D, Zhou S, Rieders J, Gregory PD, Holmes MC, Rebar EJ, High KA: In vivo genome editing of the albumin locus as a platform for protein replacement therapy. Blood 2015;126:1777-1784.

78 Glaser A, McColl B, Vadolas J: The therapeutic potential of genome editing for beta-thalassemia. F1000Res 2015;4: doi: 10.12688/f1000research.7087.1.

79 Ott de Bruin LM, Volpi S, Musunuru K: Novel genome-editing tools to model and correct primary immunodeficiencies. Front Immunol 2015;6:250.

80 Kleinstiver BP, Pattanayak V, Prew MS, Tsai SQ, Nguyen NT, Zheng Z, Joung JK: High-fidelity CRISPR-Cas 9 nucleases with no detectable genomewide off-target effects. Nature 2016;529:490-495. 